\title{
Rooting of Camu-Camu (Myrciaria dubia) in Different Propagation Systems and Reproductive Phases
}

\author{
Jhon Paul Mathews Delgado ${ }^{1}$, Patrick Mathews Delgado ${ }^{2}$, Carlos Abanto Rodriguez ${ }^{3}$ \\ \& Ricardo Manuel Bardales Lozano ${ }^{4}$ \\ ${ }^{1}$ Graduate program in Botany from the National Institute of Amazonian Research-INPA, Manaus, Brazil \\ ${ }^{2}$ Department of Parasitology, Institute of Biologly, University of Campinas, São Paulo, Brazil \\ ${ }^{3}$ Peruvian Amazon Research Institute-IIAP, Pucallpa, Ucayali, Peru \\ ${ }^{4}$ Ret Bionorte (Multinsitutional programme of Amazon), Brazil \\ Correspondence: Jhon Paul Mathews Delgado, National Institute of Amazonian Research-INPA, Manaus, AM, \\ 69067-375, Brazil. Tel: 92-8196-9696. E-mail: fedormath@hotmail.com
}

Received: January 23, 2015 Accepted: March 10, 2015 Online Published: April 15, 2015

doi:10.5539/jas.v7n5p118 URL: http://dx.doi.org/10.5539/jas.v7n5p118

\begin{abstract}
Closed environment and controlled irrigation techniques are conventionally used to root camu-camu stem cuttings. But development of other techniques of camu-camu propagation is required for smallholder growers in Peru, who cultivate camu-camu on restingas, old river levee fragments on the margins of white-water rivers. Additionally, the month in which cuttings are collected from camu-camu restingas plantations could influence their rooting capacity, influencing the effectiveness at the propagation bed stage. Here, we test propagation systems (enclosure and outdoor) and types of irrigation (watering daily with without basal reservoir and weekly watering with basal reservoir) and their combined effect on rooting of camu-camu, collected at different phenological stages (flowering and fruiting). An outdoor propagation system and weekly irrigation with basal reservoir was sufficient to root camu-camu, and can be recommended for smallholder growers of camu-camu in Peru. Phenological stage had no significant effect on either rooting percentage or camu-camu root growth. Thus, restingas camu-camu cuttings can be collected during the dry season. There was an overall average of $52 \%$ of saplings formed (cuttings with presence of roots and shoots) and $69 \%$ of cuttings with roots.
\end{abstract}

Keywords: cuttings, floodplain, Myrciaria dubia, Peruvian, propagation, saplings

\section{Introduction}

Camu-camu (Myrciaria dubia (Kunth) McVaugh, family Myrtaceae) is a shrub or small tree native to the Amazonian floodplain. It has aroused scientific and commercial interest due to the high ascorbic acid content of its fruit pulp, which ranges from 0.8 to $6.1 \mathrm{~g}$ per $100 \mathrm{~g}$. The fruit is mainly commercialized in Europe, Japan and the United States, as a source of vitamin C, and is also used in cosmetic and pharmacological products (Yuyama, 2011).

In Peru, camu-camu is usually planted by smallholders on old river levee fragments of white-water rivers called "restingas" (Halme \& Bodmer, 2007; Penn, 2006), or called "high-várzea" in Brazil (Wittmann, Junk, \& Piedade, 2004; Junk, Onhly, Piedade, \& Soares, 2000). Restingas are defined by annual inundations less than $3 \mathrm{~m}$ depth, corresponding to a mean flooded period of less than 50 days per year. In contrast, wild camu-camu grows in areas with a mean flood level of $7.5 \mathrm{~m}$; corresponding to a mean flood duration of 230 days per year. In general, restingas, are composed of nutrient-rich Entisols, primarily erosion products from the Andes (Embrapa, 2006; Junk et al., 2011; Moreira \& Fageria, 2009). They are used by small farmers who live along the margin of the rivers to cultivate species with short growing periods, such as manioc and maize. Due to the ecological characteristics of the restingas, the Peruvian government promotes camu-camu as a flood-resistant crop, an ideal fruit tree to associate with temporary crops, and as an alternative crop to increase income of wetlands-inhabiting smallholders (Pinedo, 2011; Penn, 2006).

In 1996, Peru began to promote commercial camu-camu cultivation, using seeds collected from wild plants. This initiative resulted in high phenotypic variability within plantations (Penn, 2006). Currently, camu-camu plantation plants are propagated through seeds, making it difficult to stabilize morphological characteristics of 
commercial interest (Penn, 2006).

As camu-camu is a cross-pollinated plant species, high genetic and phenotypic variability exists within populations (Yuyama \& Valente, 2011). However, Yuyama and Valente (2011) indicated that clonal propagation by cutting and clonal selection could enhance genetic gains and provide a means to stabilize morphological characteristics of interest in the shortest possible time.

A greenhouse environment with misting-based irrigation is necessary to achieve $70 \%$ to $90 \%$ rooting in camu-camu cuttings (Santana, 1998; Yuyama \& Valente, 2011). However, the construction of propagation beds demanded by that system can be economically-inviable for camu-camu-growing smallholders in Peru (Pinedo, 2011), who have an average monthly income of 18 to 80 US dollars and for whom there exists a range of additional mitigating factors, whose extent depends on social and environmental circumstances. Such factors include transport costs, drops in product prices by $10 \%$ or $20 \%$, and loss of the crops to flooding of up to $25 \%$ (Labarta, White, Leguia, Guzman, \& Soto, 2007).

The economic realities of camu-camu smallholder growers have driven a search for low-cost techniques for camu-camu propagation and cultivation. In this context, Mathews and Yuyama (2010) report 50\%-rooting in camu-camu, when used outdoor propagators and manual irrigation with 201 of water per square meter per day; dispensing with the need for greenhouses and misting-based irrigation. In Costa Rica, propagators called propagator non-mist have been developed. These consist of a wooden frame enclosed in clear polyethylene without irrigation and with a water-tight base and filled with water to a depth of $10 \mathrm{~cm}$ (Leakey et al., 1990). In Peru, under this technique, camu-camu shows up to 73\% rooting (Abanto et al., 2014, Pinedo, 2011). Although both propagation systems (outdoor and closed) show good results with camu-camu, to assess their suitability as a low-cost propagation method for rural Peruvian smallholders it is necessary to evaluate the in-tandem the effects of daily irrigation and water retention in rooting-beds.

Flooding plays an important role in the physiology (Barrera, Castro, Hernández, Fernández-Trujillo, \& Martinez, 2012) and fruit production of camu-camu (Pinedo, 2011). Fruit yield in wild camu-camu varies between years (Peters \& Vasquez, 1986/1987), and often occurs only every two years (Yuyama, 2011). On the other hand, because the level of flooding for restingas camu-camu is lower than in wild camu-camu, the harvest period can be longer.

Furthermore, depending on the duration of the dry season, camu-camu usually flowers between August and September, and harvest may occur from December to February (Inga, Pinedo, Delgado, Linares, \& Mejia, 2001; Pinedo, 2011). The physiological state of the camu-camu may be different in the flowering and harvest phases, which may influence rooting capacity (Hartmann, Kester, Daviers, \& Geneve, 1997). The reproductive phase of camu-camu is during the non-flooded season, and cuttings can be harvested under these conditions. For instance, Mathews and Yuyama (2010) found 55\% rooting success in camu-camu cuttings collected in a non-flooded season. But, a year later, in the same plantation - but when flooded - Mathews, Bardales Vasquez and Pinedo (2009) obtained $21 \%$ rooting success.

In the current study, the effect of propagation condition and irrigation type on the rooting of camu-camu was evaluated at both flowering and fruiting stages. The study aimed at producing a lower cost technique (without automatic timers and greenhouse system) for camu-camu-growing smallholders.

\section{Methods}

\subsection{Location of the Study and Climatic Data}

A rooting study was conducted in the township of Manaquiri, state of Amazonas, Brazil $\left(03^{\circ} 25^{\prime} 41^{\prime \prime} S\right.$, $60^{\circ} 27^{\prime} 34^{\prime \prime} \mathrm{W}$ ), between August 2013 and February 2014. The region has a humid equatorial climate, with a mild short dry season (July-Sep, rainfall of 50-100 mm per month), and the dry-wet transition month (Oct). The wet season extends from May to Nov (200-300 mm monthly); and the mean daily temperature is approx. $27{ }^{\circ} \mathrm{C}$ (Fisch, Marenco, \& Nobre, 1999).

\subsection{Experimental Design and Methods}

Treatments were arranged in a split-plot design with three replications. Factors were: propagation system (enclosure and outdoor) in the main plot, and irrigation type (watering daily without basal reservoir and watering weekly with basal reservoir) in the split-plot. Each sample unit had 40 cuttings. These factors were analyzed twice through two similar and independent experiments. In both assays, the plants were sampled randomly. In the first trial, the cuttings were collected from flowering plants (Aug/2013), while in the second trial they were collected from plants bearing fruits (Dec/2013). The cuttings collection period was chosen to coincide with the dry season, which generally occurs between August and December. 
Cuttings were harvested from 20 seven year-old plants growing on never-flooded land (terra firme). The cuttings came from basal sprouts (off-shoots). These were cut back to $25 \mathrm{~cm}$ lengths $8-10 \mathrm{~mm}$ in diameter. Cuttings were collected in the early morning. The basal cut of the cuttings was straight. The base of the cuttings were immersed in indole-3yl-butyric acid solutions $(200 \mathrm{ppm})$ to a depth of about $5 \mathrm{~cm}$ for 12 hours after cutting and before being inserted into the rooting medium.

Six wooden on-ground beds $(20 \mathrm{~cm} \times 100 \mathrm{~cm} \times 30 \mathrm{~cm})$ were constructed. These were divided into two compartments of equal size. In the bottom of one of the two compartments, a wooden container $(15 \mathrm{~cm} \times 95 \mathrm{~cm})$ $5 \mathrm{~cm}$ in depth and $15 \mathrm{~cm} \times 95 \mathrm{~cm}$ in width acted as post-irrigation reservoir. Finally, three of the beds were enclosed with a frame of transparent polyethylene. The experiment had $60 \%$ shading.

Fresh sawdust from a mixture of trees was used as substrate in all treatments.

We used two irrigation treatments: compartments without a basal reservoir were irrigated daily to field capacity at the beginning and middle of the day; weekly, compartments with a basal reservoir were irrigated until the reservoir was filled.

The enclosure and daily irrigation systems attempted to simulate the conventional method of camu-camu rooting, which is normally in greenhouse and under controlled irrigation.

\subsection{Data Collection and Analysis}

After 90 days, we measured the percentage of formed saplings (cuttings with presence of roots and shoots), the percentage of rooting (cuttings with roots), root number per cutting, and length of the longest root. These measurements were made for two replicates (August/2013 and December/2013). In order to adjust the data to a normal distribution standard, the percentage of formed saplings and the rooting was transformed to square root of arcsine " $x$ " (Gotelli \& Ellison, 2011).

$$
\operatorname{arcsine} \sqrt{x}
$$

Treatments were analyzed with analysis of variance (ANOVA). The comparison between treatments was via a Tukey test $(\mathrm{p}<0.05)$. The comparison between the two independent assays was performed with a T-test $(\mathrm{p}<$ $0.05)$.

\section{Results}

Propagation system and irrigation type showed no significant interaction with percentage of formed saplings, percentage of rooting, root number or root length (Table 1).

Propagation beds of closed and outdoor system no showed significant effect on rooting. Watering daily without basal reservoir and watering weekly with basal reservoir also showed no significant difference in their effect on rooting (Table 1).

The reproductive phases of camu-camu had no significant effect on rooting. Camu-camu can be collected in the flowering and fruiting phases (Table 1).

The study obtained a general average of $52 \%$ of formed samplings and $69 \%$ of rooted cuttings, regardless of the factors studied (Table 2). 
Table 1. Results of the analysis of variance for propagation system and irrigation type in the rooting of camu-camu, when collected from plants in flowering and fruiting states

\begin{tabular}{|c|c|c|c|c|}
\hline Source of variation & Formed saplings (\%) & Rooting (\%) & Root length $(\mathrm{cm})$ & Root number \\
\hline & \multicolumn{4}{|c|}{ Cuttings from plant in flowering (August/2013) } \\
\hline Propagation system & $0.006^{\mathrm{ns}}$ & $0.000^{\mathrm{ns}}$ & $0.601^{\mathrm{ns}}$ & $12.250^{\mathrm{ns}}$ \\
\hline error (plot) & 0.061 & 0.066 & 0.291 & 6.750 \\
\hline Type of Irrigation & $0.000^{\mathrm{ns}}$ & $0.001^{\mathrm{ns}}$ & $0.391^{\mathrm{ns}}$ & $6.250^{\mathrm{ns}}$ \\
\hline Irrigations x Propagation system & $0.032^{\mathrm{ns}}$ & $0.060^{\mathrm{ns}}$ & $3.516^{\mathrm{ns}}$ & $1.000^{\mathrm{ns}}$ \\
\hline \multirow[t]{2}{*}{ error (split-plot) } & 0.025 & 0.029 & 1.193 & 6.125 \\
\hline & \multicolumn{4}{|c|}{ Cuttings from plant in fruiting (December/2013) } \\
\hline Propagation system & $0.002^{\mathrm{ns}}$ & $0.012^{\mathrm{ns}}$ & $0.106^{\mathrm{ns}}$ & $7.563^{\mathrm{ns}}$ \\
\hline error (plot) & 0.003 & 0.005 & 0.204 & 5.396 \\
\hline Type of Irrigation & $0.009^{\mathrm{ns}}$ & $0.139 *$ & $0.526^{\mathrm{ns}}$ & $1.563^{\mathrm{ns}}$ \\
\hline Irrigationx Propagation system & $0.004^{\mathrm{ns}}$ & $0.000^{\mathrm{ns}}$ & $0.276^{\mathrm{ns}}$ & $10.563^{\mathrm{ns}}$ \\
\hline error (split-plot) & 0.016 & 0.018 & 1.694 & 4.063 \\
\hline
\end{tabular}

Note. $^{\mathrm{ns}}=$ not significant; $*=$ Significant $(\mathrm{p}<0.05)$. The data are the F values of ANOVA.

Table 2. Average well-developed saplings, rooting, root length and number of roots of camu-camu grown with different propagation systems, irrigation type, and reproductive phases

\begin{tabular}{|c|c|c|c|c|}
\hline & Formed saplings (\%) & Rooting (\%) & Root length (cm) & Root number \\
\hline \multicolumn{5}{|l|}{ Reproductive stage $^{a}$} \\
\hline Flowering & $41^{\mathrm{ns}}$ & $57^{\text {ns }}$ & $4.3^{\mathrm{ns}}$ & $5.8^{\mathrm{ns}}$ \\
\hline Fruiting & 43 & 61 & 3.8 & 4.8 \\
\hline \multicolumn{5}{|l|}{ Propagation system $^{b}$} \\
\hline Closed & $45^{\mathrm{ns}}$ & $63^{\text {ns }}$ & $3.9^{\mathrm{ns}}$ & $5.8^{\mathrm{ns}}$ \\
\hline Outdoor & 38 & 55 & 4.2 & 4.8 \\
\hline \multicolumn{5}{|l|}{ Type of Irrigation $^{c}$} \\
\hline daily without basal reservoir & $42^{\mathrm{ns}}$ & $58^{\mathrm{ns}}$ & $4.0^{\mathrm{ns}}$ & $4.5^{\mathrm{ns}}$ \\
\hline weekly with basal reservoir & 41 & 60 & 4.1 & 6.1 \\
\hline Mean total ${ }^{\mathrm{d}}$ & $42 \pm 14$ & $60 \pm 16$ & $4.0 \pm 1$ & $5.3 \pm 2.4$ \\
\hline
\end{tabular}

Note. $^{\text {ns }}=$ not significant. Comparison tests $=$ a. For T-test $(\mathrm{p}<0.05)$; b e c. For ANOVA. d. mean \pm standard deviation.

\section{Discussion}

Both cutting types propagated under closed and outdoor systems exhibited statistically similar rooting frequencies. Closed systems propagation beds of are more commonly used for cuttings which are less resistant to hydric stress, such as those with softwood or herbaceous stems. By contrast, outdoor systems propagation beds are generally used for rooting of hardwood stem cuttings, such as those used in our study (Hartmann, Kester, Daviers, \& Geneve, 1997).

In general, the percentage of rooted cuttings achieved in this study (Table 2) is similar to that reported by Mathews and Yuyama (2010) (55\%) using a system with outdoor propagation beds and daily irrigation. However, the agronomic advantages of our method include: (i) the use of offshoot-derived cuttings (ii) cutting smaller than $10 \mathrm{~mm}$ in diameter. In camu-camu offshoots of this size and origin are abundant in plants in the third and seventh year of planting. This may make them preferable to the method of Mathews and Yuyama (2010) who used larger diameter branches $(2.5$ to $3.5 \mathrm{~cm}$ ) derived from 10 year-old trees. In consequence, the type of cutting used in the 
current study offers the possibility of selecting and propagating plants more quickly than those used by Mathews and Yuyama (2010). In addition, the use of thick cutting requires a drastic pruning of camu-camu main branches.

The percentage of rooting in the present study was lower than that reported by Yuyama and Valente (2011) [52\% versus $90 \%$ rooting], who also used propagation system enclosure and daily irrigation. However, Yuyama and Valente (2011) did not clarify whether the rooting percentage consisted of cuttings with both roots and shoots. This is important because in camu-camu approximately $10 \%$ of rooted cuttings fail to develop shoots (Mathews et al., 2009; Santana, 1998).

Using propagation beds in outdoor environments plus daily irrigation, Mathews and Yuyama (2010) obtained higher mean numbers of roots $(12 \pm 2.1$ roots $)$ and greater mean root length $(11 \pm 1.4 \mathrm{~cm})$ per camu-camu cuttings that in our study ( $4 \pm 1$ roots and $5.3 \pm 2.4 \mathrm{~cm}$ root length). Probably, the use of humus derived from sawdust by these authors had a positive effect on the development of the roots, contrary to our study where fresh sawdust was used. However, camu-camu forms roots regardless of the substrate fertility, and roots improve its development in the nursery (Santana, 1998).

It is likely that the use of off-shoots has facilitated rooting (Yuyama \& Valente, 2011), regardless of the reproductive phase in camu-camu. Certainly, basal shoots from young branches root prolifically in several forest species such as Cordia alliodora (Ruiz \& Pav.) Oken, Vochysia hondurensis Sprague, Albizia guachapale (Kunth) Dug., Gmelina arborea Roxb., and Eucalyptus deglupta BL. (Leakey et al., 1990), this latter of Myrtaceae family as Myrciaria dubia. Thus, while the cuttings in the study were collected in August and December of the same year, it is likely that camu-camu cuttings can be collected at the beginning and end of the dry season in restingas camu-camu.

\section{Conclusion}

Outdoor propagation beds with weekly watering and a basal reservoir can be recommended for smallholder camu-camu growers in Peru. This propagation system can replace the closed with controlled irrigation system often used to root camu-camu.

Flowering and fruiting phase not affect the rooting of the camu-camu, and cuttings may be collected from unflooded plantations of restingas camu-camu.

\section{Acknowledgments}

The authors would like to thank the graduate program in Botany of the National Institute of Amazonian Research-INPA. This work was financially supported by the CNPq (National Council for Scientific and Technological Development), Brazil. Juan Revilla Cardenas for logistical support. Adrian A. Barnett helped with the English.

\section{References}

Abanto, R. A., Chagas, A. E., Sánchez-Choy, J., dos Santos, A. V., Bardales, L. R. M., \& Ríos, G. S. (2014). Capacidad de enraizamiento de plantas matrices promisorias de Myrciaria dubia (Kunth) Mc Vaugh en $\begin{array}{llllll}\text { cámaras de } & \text { subirrigación. } & \text { Rev. } & \text { Ceres, } & \text { 61(1), }\end{array}$ http://dx.doi.org/10.1590/S0034-737X2014000100018

Barrera, J. A., Castro, S. Y., Hernández, M. S., Fernández-Trujillo, J. P., \& Martínez, O. (2012). Maximum Leaf Photosynthetic Light Response for Camu Camu (Myrciaria dubia Kunth McVaugh) Plants in Three Growth Stages in the South Colombian Amazonian Region. Acta Hort., 928, 193-198.

Empresa Brasileira de Pesquisa Agropecuária. (2006). Sistema brasileiro de classificação de solos. Rio de Janeiro: Empresa Brasileira de Pesquisa Agropequaria Solos.

Fisch, G., Marenco, J. A., \& Nobre, C. A. (1999). Uma revisão geral sobre o clima da Amazônia. Acta Amazonica, 28, 101-126.

Gotelli, N. J., \& Ellison, A. M. (2011). Princípios de estatística em ecologia. Porto Alegre: ARMED EDITORA S.A.

Halme, K. J., \& Bodmer, R. E. (2007). Correspondence between scientific and traditional ecological knowledge: Rain forest classification by the non-indigenous ribereños in Peruvian Amazonia. Biodivers Conserv, 16, 1785-1801. http://dx.doi.org/10.1007/s10531-006-9071-4

Hartmann, H. T., Kester, D. E., Daviers, Jr. F. T., \& Geneve Robert, L. (1997). Plant Propagation: Principles and Practice. New Jersey: Prentice-Hall, Inc.

Inga, H., Pinedo, M., Delgado, C., Linares, C., \& Mejia, K. (2001). Fenologia reprodutiva de Myrciaria dubia 
McVaugh (H.B.K.) camu-camu. Folia Amazonica, 12, 1-2.

Junk, W. J., Onhly, J. J., Piedade, M. T. F., \& Soares, M. G. M. (2000). The central Amazon Floodplain: Actual use and options for a sustainable Management. Leiden: Backhuys. http://dx.doi.org/10.1007/s13157-011-0190-7

Junk, W. J., Piedade, M. T. F., Schöngart, J., Cohn-Haft, M., Adeney, M., \& Wittmann, F. (2011). A Classification of major naturally-occurring Amazonian lowland wetlands. Wetlands, 31, 623-640.

Labarta, R., White, D., Leguía, E., Guzmán, W., \& Soto, J. (2007). La Agricultura en la Amazonia Ribereña del Río Ucayali: Una Zona Productiva pero Poco Rentable? Acta amazonica, 37(2), 177-186. http://dx.doi.org/10.1590/S0044-59672007000200002

Leakey, R. R. B., Mesen, J. F., Tchoundjeu, Z., Longman, K. A., Dick, J. McP., .. Muthoka, P. N. (1990). Low-technology techniques for the vegetative Propagation of tropical trees. Commonw. For. Rev., 69(3), 247-257.

Mathews, D. J. P., \& Yuyama, K. (2010). Cutting lenght of camu-camu with indolebutyric acid for clonal production. Rev. Bras. Frutic., 32(2), 522-526.

Mathews, D. J. P., Bardales, R., Vásquez, D. C., \& Pinedo, P. M. (2009). Enraizamento de estacas de camu-camu com diferentes diâmetros sob diferentes concentrações do ácido indolbutírico. In A. E. Guamão (Ed.), I Workshop Agricultura No Trópico Úmido (pp. 13-15). Manaus, Brazil: Post Graduate Program in Agriculture in the Humid Tropics, National Institute of Amazonian Research.

Moreira, A., \& Fageria, N. K. (2009). Soil Chemical Attributes of Amazonas State, Brazil. Communications in Soil Science and Plant Analysis, 40, 2912-2925. http://dx.doi.org/10.1080/00103620903175371

Penn, J. W. (2006). The cultivation of camu camu (Myrciaria dubia): A tree planting programme in the Peruvian amazon. Forests, Trees and Livelihoods, 16, 85-101. http://dx.doi.org/10.1080/14728028.2006.9752547

Peters, C. M., \& Vásquez, A. (1986/1987). Estudios ecológicos de camu-camu (Myrciaria dubia). I. Producción de frutos en poblaciones naturales. Acta Amazonica, 16/17, 161-174.

Pinedo, P. M. (2011). Сamu-camu (Myrciaria dubia, Myrtaceae). Aportes para su aprovechamiento sostenible en la Amazonía peruana. Iquitos: Research Institute of the Peruvian Amazon/IIAP

Santana, S. C. (1998). Propagação de camu-camu por estaquia. Biotecnología Ciência \& Desenvolvimento, 29. http://dx.doi.org/10.1590/S0100-29452011000200001

Wittmann, F., JunK, J. W., \& Piedade, M. T. M. (2004). The várzea forests in Amazonia: Flooding and the highly dynamic geomorphology interact with natural forest succession. Forest Ecology and Management, 196, 199-212. http://dx.doi.org/10.1016/j.foreco.2004.02.060

Yuyama, K. (2011). A cultura de camu-camu no Brasil. Rev. Bras. Frutic., 33, $335-690$. http://dx.doi.org/10.1590/S0100-29452011000200001

Yuyama, K., \& Valente, J. P. (2011). Camu-camu (Myrciaria dubia (Kunth) Mac Vaugh). Curitiba: CRV.

\section{Copyrights}

Copyright for this article is retained by the author(s), with first publication rights granted to the journal.

This is an open-access article distributed under the terms and conditions of the Creative Commons Attribution license (http://creativecommons.org/licenses/by/3.0/). 